| Original | Article |

\title{
Effect of extracts of Allium porrum in some hematological parameters of
}

\section{rat}

\author{
Azhar Shya Y. Albsaysi
}
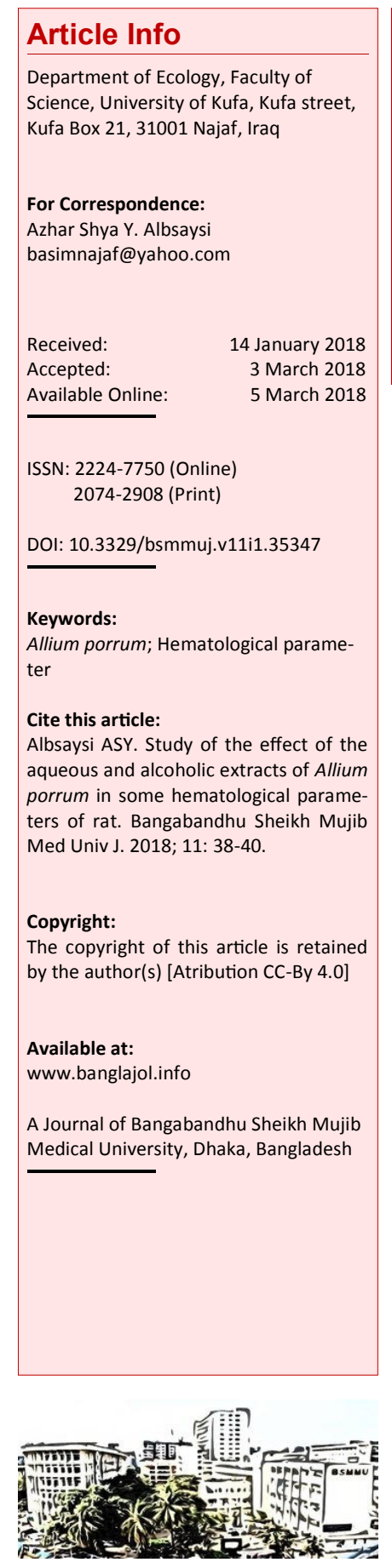

\section{Abstract}

The research was aimed to know the effect of aqueous and alcoholic extracts of Allium porrum on some hematological parameters of male rats $(n=35)$. Rats were divided into groups and were administrated different concentrations $(200,400$, and 800$) \mathrm{mg} / \mathrm{kg}$ of extract daily for one week to study the parameters of hematological parameters compared to control group. The treatment with A. porrum extracts led to increasing RBC and P.C.V. for all extract concentrations and to both kinds. The aqueous extract $800 \mathrm{mg} / \mathrm{kg}$ shows more significant effect than the other levels. A significant increase in hemoglobin concentration for aqueous extract $800 \mathrm{mg} / \mathrm{kg}$ and $400 \mathrm{mg} / \mathrm{kg}$ and alcoholic extract $800 \mathrm{mg} / \mathrm{kg}$ and alcoholic extract $800 \mathrm{mg} / \mathrm{kg}$ were more significant than the other levels and a significant decrease in WBC count for alcoholic extract $400 \mathrm{mg} / \mathrm{kg}$ compared to the control group.

\section{Introduction}

Medical plants have grown significant sources of phytosanitary drugs or active substances that used in the preparation of drugs. $\underline{1,2}$ Medicinal plants contain the secondary metabolic products produced by them as natural products known for their essential biological and pharmacological activity and as chemical agents. This literature is considered a starting point in the formation and development of modern medicine. $\underline{3,4}$

This study is to observe the changes in hematological parameters, measure the amount of blood hemoglobin, and calculate the size of blood cells packed cell volume (PVC) of rat using the aqueous and alcohol extracts of the widespread Allium porrum (leek plant) in Iraq.

\section{Materials and Methods}

In this study, 35 male rats were used. Rats were divided into groups, the first injected with the phthalic solution. The second, third and fourth groups mixed with an aqueous extract at a concentration of 200, 400 and $800 \mathrm{mg} / \mathrm{kg}$, respectively. While the fourth, fifth and sixth groups injected with a concentrated alcohol extract of 200, 400 and $800 \mathrm{mg} / \mathrm{kg}$, respectively. They were given daily for a week. After 24 hours of the last dose, the animals were weighed and anesthetized with ether, and the blood withdrawn with $1 \mathrm{~mL}$ syringe. The blood was removed from the heart directly and kept in tube containing EDTA for blood tests. Dacie and Lewis (1984) method was adopted using the hemocytometer after blood dilution of 200: 1 with Hymes solution and the number of red blood cells calculated in the small squares according to the following equation 5 :

No. of red blood cells in $1 \mathrm{~mm}^{3}=$ Number of cells in five squares $x 10,000$

Large quantities of leek leaves were collected from the field where the leaves were well washed and cleaned from dust and dirt and then dried well and then grinded and turned into dry powder. It was then used to prepare the extracts. Harborne, 1974 method was used to prepare the hot water extract for leek leaves. 6 $100 \mathrm{~g}$ of dried leaves powder was taken and placed in 1,000 mL of distilled boiled water with well mixing for $15 \mathrm{~min}$ and leaving the beaker for $30 \mathrm{~min}$. The solution was filtered through a cloth and placed in a centrifuge for 3,000 rpm for $15 \mathrm{~min}$. The filtrate was then placed in glass bottles. The glass bottles containing the liquid extract were placed in an electric oven for $40 \mathrm{~min}$. Then filtered through a filter paper by millipore for the purpose of sterilization and then return to the electric oven to obtain a dry extract. Then the sample was stored in a refrigerator. $20 \mathrm{~g}$ of dry powder of plant leaves was placed in thimbles in the Soxhlet extractor. $600 \mathrm{~mL}$ of ethyl alcohol was added and the extraction was carried out within 24 hours and the sample evaporated in a rotary evaporator at $40^{\circ} \mathrm{C}$ and low pressure. 
After obtaining the gelatinous solution, apply during millipore for the purpose of sterilization. Then it was put in the oven at $40^{\circ} \mathrm{C}$ to obtain a dry extract.

The method of Dacie and Lewis (1984) was adopted using the blood cell count after dilution of blood by 20:1 by the solution of nitrate according to the following equation 5 :

No. of white blood cells in $1 \mathrm{~mm}^{3}=$ Number of white blood cells in large squares $x 50$

The method of hematocrit used in Dacie and Lewis (1984) as blood drawn by capillary tube containing a coagulation inhibitor. .5 One of the ends was closed with synthetic clay and placed in a microcentrifuge at $10,000 \mathrm{rpm}$ for $10 \mathrm{~min}$.

According to Makarem (1974), hemoglobin was estimated using the special test kits manufactured by Randox, using the spectrophotometer, to measure the level of hemoglobin in the blood.?

\section{Statistical analysis}

The $\mathrm{t}$-Student test was used to find the moral significance. Low Significance Differences (LSD) were also used to compare the rates as well as the standard methods used to determine the mean and Standard deviation (SD). ?

\section{Results}

Table I shows a significant increase $(p<0.05)$ in the number of red blood cells in all groups treated with leek extract compared to the control group, as it was $0.9 \pm 6$ million cells $\mathrm{kg} \mathrm{mm}^{-3}$. The highest value was $7.9 \pm 1.7$ million cells $\mathrm{mg} \mathrm{kg}^{-3}$ in the treatment group with the aqueous extract $800 \mathrm{mg} / \mathrm{kg}$. Table I shows a significant decrease $(\mathrm{p}<0.05)$ of the number of white blood cells in the treated group with the extract of $400 \mathrm{mg} / \mathrm{kg}$ compared to the control group $\left(6.4 \pm 0.3\right.$ million cells $\left.\mathrm{mm}^{-3}\right)$. Whereas, is decreased to $5.0 \pm 0.4$ million cells $\mathrm{mm}^{-3}$ in the group treated with alcohol extract $400 \mathrm{mg} / \mathrm{kg}$. The value of PVC increased in all treatment groups compared with control group. It was $40.3 \% \pm 2.1$ and increased of $47.8 \% \pm 0.9$ in the group treated with the aqueous extract $800 \mathrm{mg} / \mathrm{kg}$ (Table I). Tables I shows a significant increase $(\mathrm{p}<0.05)$ in hemoglobin in the treatment groups with the aqueous extract 400 and $800 \mathrm{mg} / \mathrm{kg}$ and the alcoholic extract by $800 \mathrm{mg} / \mathrm{kg}$ compared to the control group $13.7 \pm 0.7 \mu \mathrm{m}$. The highest value was $17.9 \pm 1.0 \mu \mathrm{m}$ in the treatment group with alcohol extract $800 \mathrm{mg} / \mathrm{kg}$.

\section{Discussion}

The results showed a significant increase of the number of red blood cells in all groups treated with leek extract, as well as a considerable increase in the size of blood cells, as well as a significant increase in hemoglobin. The increase in the number of red blood cells means an increase in the activity of dividing cells in bone marrow by the extract. This result agreed with the findings of Hassan and Ahmed (2002) in the white mice with a dose of 200 $\mathrm{mg} / \mathrm{kg}$ of alcohol and aqueous extract of the black sesame seed for a week led to a significant increase in mitosis of the cells of the bone. 8 The increased concentration of the extract leads to the rise in the division. The reason for this increase is the black sesame seed, which contains catalysts for the process of division. This result is consistent with Haq et al. (1995) as the black sesame seed contains mitogen substances and their ability to stimulate cells to divide without adding any other catalysts. 9 This increase in red blood cell production explained by increased blood cell size and increased hemoglobin. The number of white blood cells was not significantly affected in the treatment groups except the treatment by the aqueous extract 400 $\mathrm{mg} / \mathrm{kg}$. This decrease may attribute to the fact that high concentrations of the extract cause stress, which affects the preparation of white blood cells. This finding is consistent with Al-Muzayel and Snake (2001), who observed a decrease in the number of white blood cells when treated with high doses of black seed semen.10 This finding differed with Ayoub (1999), who observed increased numbers of these cells at high doses $800 \mathrm{mg} / \mathrm{kg} .11$

\begin{tabular}{|c|c|c|c|c|c|c|c|}
\hline \multicolumn{8}{|c|}{ Table I } \\
\hline \multicolumn{8}{|c|}{ Effects of the aqueous and alcohol extracts on the physiological parameters } \\
\hline \multirow[t]{2}{*}{$\begin{array}{l}\text { Hematological parame- } \\
\text { ters }\end{array}$} & \multirow[t]{2}{*}{$\begin{array}{l}\text { Control } \\
\text { animals }\end{array}$} & \multicolumn{3}{|c|}{$\begin{array}{l}\text { Animals treated with aqueous extract } \\
\qquad(\mathrm{mg} / \mathrm{kg})\end{array}$} & \multicolumn{3}{|c|}{$\begin{array}{l}\text { Animals treated with alcohol extract } \\
\qquad(\mathrm{mg} / \mathrm{kg})\end{array}$} \\
\hline & & 200 & 400 & 800 & 200 & 400 & 800 \\
\hline $\mathrm{RBC} \times 10^{6}$ & $6 \pm 0.9$ & $7.3 \pm 0.7 \mathrm{a}$ & $6.8 \pm 0.9 a$ & $7.9 \pm 1.7 \mathrm{a}$ & $7.3 \pm 0.5^{a}$ & $7.6 \pm 0.7 \mathrm{a}$ & $7.5 \pm 0.5^{a}$ \\
\hline $\mathrm{WBC} \times 10^{3}$ & $3.6 \pm 0.3$ & $3.5 \pm 0.5$ & $3 \pm 0.5$ & $2.9 \pm 0.4$ & $2.8 \pm 0.5$ & $3.1 \pm 0.5$ & $3.7 \pm 0.5$ \\
\hline P.C.V & $40.3 \pm 2.1$ & $44.7 \pm 0.7$ & $45.3 \pm 0.6$ & $47.8 \pm 0.9$ & $43 \pm 0.9$ & $46.8 \pm 0.9$ & $45.2 \pm 0.5$ \\
\hline Hemoglobin $(\mathrm{g} / 100 \mathrm{~mL})$ & $13.7 \pm 0.7$ & $14 \pm 0.5$ & $16.3 \pm 0.7^{a}$ & $16 \pm 0.5^{\mathrm{a}}$ & $15.3 \pm 0.7$ & $15.7 \pm 0.7$ & $17.9 \pm 1.0^{\mathrm{a}}$ \\
\hline
\end{tabular}




\section{Acknowledgements}

The author acknowledges the financial support of the University of Kufa, Iraq. The author is grateful to Dr. Basim A. Almayahi, Department of Ecology, College of Science, University of Kufa (basimnajaf@yahoo.com) for assisting me throughout conducting the present research.

\section{References}

1. Shahat, Zeid NA. Volatile oils. Arab Publishing House and Distribution, Cairo, Egypt, 2000.

2. Taha KF. Medicinal plants cultivated and ingredients. Arabic Book House, Libya, 1979.

3. Verpoorte R. Pharmacognosy in the new millennium: Lead finding and biotechnology. J Pharm Pharmacol. 2000; 52: 253-62.

4. Ishizuka M, Kawatsu M, Yamashita $T$, Ueno $M$, Takeuchi T. Low molecular weight immunomodu lators produced by microorganisms. Int J Immunopharmacol. 1995; 17: 133-39.

5. Dacie JV, Lewis SV. Practical hematology. $6^{\text {th }}$ ed. Churchil Livingston, 1984.
6. Makarem A. Clinical chemistry: Principles and techniques. 2nd ed. Henry RF, Cannon OC, Winkelman JW (eds). Harper and Row, Hgerstown, 1974, 1128-35.

7. Al-Rawi, Mahmoud K. Introduction to statistics. 2nd ed. Faculty of Agriculture and Forestry, University of Mosul, 2000.

8. Hassan, Ahmed MQ. Use of some plant extracts to inhibit the toxicological effect of some anti-cancer drugs in the mouse. PhD. Faculty of Science University of Babylon, 2002.

9. Haq A, Abdullatif M, Lobo PI, Khabar KS, Sheth KV, Al-Sedairy ST. Nigella sativa effect on human lymphocytes and polymorphonuclear leukocyte phagocytic activity. Immunopharmacology 1995; 21: 283-95.

10. Al-Muzayel, Snake AJ. A comparative study of the effect of aspirin and some medicinal plants on various life chemical variables in rabbits' blood. Master Thesis- Faculty of Science- University of Babylon, 2001.

11. Ayoub RS. Effect of high dose of the aqueous extract of Nigella sativa seeds on blood glucose level and leukocyte count in rats. Iraqi J Veterinary Sci. 1999; 12: 61-65. 